Ткачук Д.Г., аспірант НАДУ при Президентові Украӥни, м. Київ, ORCID: 0000-0001-7439-2770

Tkachuk D., PhD student, Department of Social and Humanitarian Policy, National Academy of Public Administration under the President of Ukraine, Kyiv

\title{
ОСОБЛИВОСТІ ДІЯЛЬНОСТІ ПРЕДСТАВНИЦЬКИХ ОРГАНІВ КРИМСЬКОТАТАРСЬКОГО НАРОДУ ЯК СУБ'СКТІВ ДЕРЖАВНОЇ ЕТНОПОЛІТИКИ
}

\section{PECULIARITIES OF ACTIVITY OF REPRESENTATIVE BODIES OF THE CRIMEAN TATAR PEOPLE AS SUBJECTS OF THE STATE ETHNOPOLITICS}

Метою дослідження статті є представлення особливостей діяльності представницьких органів кримськотатарського народу як суб 'єктів державної етнополітики від перших років незалежної Украӥни до подій, пов'язаних з анексією Криму Російською Федерачією у 2014 рочі. Такий проміжок часу дозволить представити політичний аналіз особливостей діяльності представницьких органів кримських татар у соціальному, політичному та економічному плані в різних формах взаємодії у сфері державної етнополітики в Украӥні.

Ключові слова: кримські татари; анексія Кримського півострова; Україна; етнос; етнополітика; Меджліс; Курултай.

The purpose of the study is to present the features of the representative bodies of the Crimean Tatar people as subjects of state ethnopolitics from the first years of independent Ukraine to the events related to the annexation of Crimea by the Russian Federation in 2014. This period of time will allow to present a political analysis of the peculiarities of the activities of the representative bodies of the Crimean Tatars in social, political and economic terms in various forms of cooperation in the field of state ethnopolitics in Ukraine.

Key words: Crimean Tatars; annexation of the Crimean peninsula; Ukraine; ethnos; ethnopolitics; Majlis; Kurultai.

Постановка проблеми. Масовий наплив татар до Криму мав місце у 1989-1999 рр. Це слід пояснити супутніми обставинами, тобто зусиллями лідерів татарського руху протягом десятиліть до побудови та підтримки на- 
ціональної свідомості - i, на їх думку, повернення на півострів було специфічним обов'язком. Ідея повернення була дуже сильною серед татарської діаспори. На їх думку, лише на своїй "історичній батьківщині" вони могли культивувати свої традиції та культуру. Це було тим важливіше, що близько 60\% повернутих татар вже народилися в Середній Азії. 26 червня 1991 року в Сімферополі відбувся перший з'їзд кримських татар, саме з цієї події можемо вважати початок діяльності представницьких органів кримськотатарського народу, як суб'єкту державної етнополітики в Україні, під час згаданого з'їзду, було оголошено, що Крим є національною територією татар, де лише вони мають право на самовизначення. У жовтні 1991 року українська влада скасувала обмеження щодо повернення до Криму, накладені на кримських татар. В результаті близько 90\% з них повернулися із Центральної Азії (переважно з Узбекистану) на Кримський півострів. Надійні статистичні дослідження в Україні вперше були проведені в 2001 році. На той час перепис населення показав, що в Криму етнічні росіяни становлять найбільшу групу жителів, тобто 58,3\% від загальної кількості населення півострову, тобто 1280400 осіб (хоча цей відсоток знизився порівняно з 1989 роком, коли вони на той час становили 65,6\%). На півострові проживало 492 200 українців, тобто 24,3\% від загальної кількості населення (це значення зменшилось порівняно з 1989 роком, коли становило 26,7\%). На той час чисельність кримських татар становила 243400 осіб, що становило 12\% населення (це було збільшення порівняно з 1989 роком, коли вони становили лише $1,9 \%$ ). Динамічне зростання татар на Кримському півострові слід пояснити подальшою репатріацією. Однак для цієї громади характерні також вищі показники народжуваності та нижчий середній вік. Це може призвести до збільшення відсотка татар у Криму [1].

Виклад основного матеріалу. Повернення такої великої групи татар викликало велике занепокоєння серед українців та росіян, які проживають на Кримському півострові. Вони були пов'язані в першу чергу з тим, що вони претендуватимуть на право повернути собі домівки та землю, оскільки татари вважали себе корінним населенням півострова [17, с. 267]. У 1991 році влада новоствореної української держави не мала чіткої стратегії у сфеpi етнічної політики щодо повернення кримських татар. На початковій фазі репатріації вони мали позитивне ставлення, що було обумовлено в основному бажанням змінити етнічну структуру в Криму, де більшість складали росіяни, серед яких були сепаратистські прагнення. Однак згодом питання про кримських татар та інших національних меншин в Україні набуло в державній етнополітиці другорядного значення [10]. Відсутність фінансової та матеріально-технічної підтримки репатріантів та низькі ціни, за які вони продали все своє майно в країнах Центральної Азії, призвели до нездатності адаптуватися до нових умов життя. Це спричинило відчуження татар і призвело до високого рівня безробіття серед цього населення. Крім того, вони стикалися 3 формальними та юридичними проблемами 3 можливістю осели- 
тися та прийняти громадянство [14]. Місцева влада не погодилася на повернення татар на південне узбережжя Криму. В результаті вони в основному оселилися в смузі Бахчисарай - Старий Крим - Керч. У 2005 році татари почали незаконно поселятися в прибережних районах, що спричинило суперечки 3 місцевою владою. Вони діяли на основі здійсненого факту, тим самим змушуючи легалізувати своє перебування [10].

Саме відсутність ефективного діалогу 3 представницькими органами кримськотатарського народу та чіткої сформованої державної етнополітики, щодо визнання кримських татар їі повноцінним суб'єктом, призвели до згаданих непорозумінь на рівні місцевої та вищої влади. Українська влада попросила допомоги у реінтеграції кримськотатарського товариства УВКБ ООН. Ця організація розпочала свою роботу в 1996 році. Вона здійснила низку програм фінансової підтримки, спрямованих на комплексне вирішення проблеми кримських татар, та їх представницьких органів як суб'єктів державної етнополітики. Однією з проблем було те, що ціна від продажу нерухомості в країнах Центральної Азії не дозволяла купувати нерухомість у Криму. Саме з цієї причини УВКБ ООН розпочало роботу у 2002 році програму фінансування будинків для репатріантів. Ще однією проблемою був статус репатріантів та їх громадянство. Понад 100000 кримських татар, які прибули на Кримський півострів, не мали українського громадянства, що ускладнювало пошук роботи, освіти, медичної та соціальної допомоги. Такий стан справ тривав до 1997 року, коли в серпні 1998 року з метою спрощення процедур уряди Узбекистану та України підписали угоду про запобігання подвійному громадянству, що пришвидшило та спростило процес відмови від узбецького громадянства та отримання громадянства України. Це дозволило набути громадянські права та сприяло зменшенню дискримінації, принаймні формальної, щодо татарського суспільства [10].

Повернувшись до Криму, татари створили власні представницькі органи, що автоматично ставали суб'єктами державної етнополітики в Україні, засоби масової інформації та телеканали рідною мовою в незалежній Україні [17, с. 274]. Україна є членом Ради Європи з 9 листопада 1995 року. Вона підписала та ратифікувала низку угод, що захищають права національних меншин, в т.ч. Конвенція про захист прав людини та основних свобод, Рамкова конвенція про захист національних меншин та Європейська хартія регіональних мов або мов меншин. Стаття 11 Конституції України гарантує права національних меншин, зазначаючи, що: «Держава підтримує консолідацію та розвиток української нації, іï історичної свідомості, традицій та культури, а також розвиток етнічної, культурної, мовної та релігійної самобутності всіх корінних народів та національних меншин України» [3, с. 64]. Крім того, 25 червня 1992 року українська влада прийняла Закон 2494 - XII про національні меншини: «Про національні меншини в Україні» [9]. Переважна більшість кримських татар - мусульмани-суніти.

Для відстоювання своїх прав ще в 1991 році кримські татари створили 
місцеве самоврядування, як суб'єкт державної етнополітики в Україні. До його головних елементів належать - Курултай - з'їзд кримських татар та Меджлісу кримськотатарської нації. Курултай складається з 250 делегатів, обраних кримськими татарами на 5-річний термін від татарських громад. Курултай бере участь у політичних, соціальних, економічних, культурних та інших проблемах, що мають ключове значення для кримських татар. Він обирає органи Курултаю та членів Меджлісу [4]. Меджліс кримськотатарської нації є вищим представницьким та виконавчим органом у період між засіданнями Курултаю. Вже на першому засіданні у 1991 році він прийняв державний гімн та відзнаки кримських татар. Це найвищий уповноважений орган татар і в першу чергу виконує виконавчі функції. Згідно зі своїм статутом, основною метою Меджлісу є усунення наслідків геноциду, скоєного Радянською державою для кримських татар, відновлення національних та політичних прав татарського народу, а також діяти як представницький орган кримських татар, як суб'єкт державної етнополітики в Україні, який може подавати скарги до центрального уряду України, уряду Криму та міжнародних органів. У своїй діяльності Меджліс підзвітний Курултаю і виконує його рішення.

Меджліс кримськотатарської нації складається з 33 членів, обраних 3 числа делегатів Курултаю, включаючи голову. Штаб-квартира Меджілісу до анексії Криму знаходилась у місті Сімферополі. 3 часу заснування Меджлісу в 1991 - 2013 роках його головою був Мустафа Джемілєв, якого татари вважають беззаперечним моральним та політичним авторитетом. Однак 3 жовтня 2013 року цю посаду обіймає Рефат Чубаров [5]. 3 часу створення незалежної української держави в 1991 році кримські татари прагнули до правового регулювання статусу Меджлісу та їх самоврядування, створюючи власні представницькі органи, як суб'єкт державної етнополітики в Україні. Однак, корінною особливістю діяльності такого представницького органу як Меджліс, була його кінцева ідентифікація юридичного статусу (орган не зареєстрований в Мінюсті як громадсько-політична організація), та довгий час невизнання його, як основного органу самоврядування кримськотатарського народу. Не вдалися до рішучих дій, щодо Меджілісу за часів своєї каденції і Леонід Кучма і Віктор Янукович і навіть відкрито прозахідний президент Віктор Ющенко [12].

Однак українська влада де-факто визнала діяльність Меджлісу, як представницького органу та суб'єкт державної етнополітики в Україні та провела з ним переговори. Це було набагато простіше, тому що його вищі керівники засідали в парламенті України. Лише після анексії Росією Криму, тобто 20 березня 2014 року, Верховна Рада України прийняла Акт про гарантії прав кримськотатарського народу в межах української держави. Цей акт гарантує збереження та розвиток етнічної, культурної, мовної та релігійної самобутності кримських татар та надає їм статус корінних народів. Це гарантувало захист та здійснення невід'ємного права на самовизначення татар- 
ського народу в суверенній та незалежній державі Україні.

Крім того, він визнав Меджліс кримських татар і Курултай найвищим представницьким органом кримських татар, як суб'єкта державної етнополітики в Україні [10]. 12 листопада 2015 р. Верховна Рада ухвалила постанову «Про визнання геноциду кримськотатарського народу» та оголосила 18 травня Днем пам’яті жертв злочинів проти кримських татар [8].

3 точки зору регіональної безпеки, анексія Кримського півострова Російською Федерацією в 2014 році принципово змінила існуючий баланс сил у басейні Чорного моря. Втрата Кримського півострова для уряду в Києві призвела до значного зменшення економічного, військового та населення. Для кримських татар дії української влади, яка не активно захищала Крим, стали великим розчаруванням, тим більше, що керівники Меджлісу (нинішній - Рефат Чубаров та колишній - Мустафа Джемілєв) підтримали Свромайдан. У Сімферополі відбулися демонстрації проти дій Росії в Криму, організовані татарським народом. У ніч з 27 на 28 лютого 2014 року на Кримському півострові російськими солдатами у військовій формі без знаків розрізнення була проведена військова операція. Через відсутність емблем їх називали «зеленими чоловічками».

Меджліс кримськотатарської нації протестував проти проведення «референдуму» проросійськими політиками, закликаючи до сильного бойкоту і засуджуючи російську агресію на Кримському півострові. Згідно 3 офіційними результатами референдуму, представленими окупаційною владою, 96,77\% жителів півострова проголосували за незалежність Криму від України та приєднання до Росії. 1841073 виборці мали право голосу, тоді як 1548197 осіб віддали свої голоси. Явка склала 84,09\% [7]. Міжнародне співтовариство не визнало референдум, і представлені результати поставили під сумнів багато незалежних спостерігачів. Свген Бобров - один із членів Ради 3 питань розвитку громадянського суспільства та прав людини при Президентові Російської Федерації - представив інформацію про те, що близько 50-60\% жителів Криму проголосували за приєднання його до Росії, а явка склала близько 30-50\%.

3 іншого боку, Мустафа Джемілев стверджував, що, за даними громади кримських татар, явка на референдум становила лише близько $32 \%$. Крім того, заступник голови Меджлісу - Ахтем Чийгоз - заявив, що явка серед кримських татар коливалася приблизно від 30 до 40\%.

Висновки. Кримські татари вважаються корінним населенням Кримського півострова. Протягом століть вони створювали власну державність, культивували свої традиції та культуру. Після розпаду СРСР кримські татари почали масово прибувати на Кримський півострів. Влада новоствореної української держави, на жаль, в перші роки своєї діяльності та формування етнополітичного курсу щодо представницьких органів кримськотатарського народу не розробила жодної стратегії в сфері державної політики. Жодних нормативно-правових актів не розроблялося, а також в перші роки незалеж- 
ності не вживались заходи, які могли б допомогти кримськотатарському народу та їх новоствореним представницьким органам. Це призвело до політизації соціальних, економічних та культурних настроїв, а отже, і національної напруженості між жителями Криму. Слід зазначити, Меджліс, що є представницьким органом кримськотатарського народу, як суб'єкту державної етнополітики - відіграв дуже важливу роль у створенні політичних та соціальних процесів стосовно цієї нації, хоча він і не був початково визнаний українською владою. Турбота про гарантії прав кримськотатарського народу в межах української держави - на сьогодні забезпечує збереження та розвиток етнічної, культурної, мовної та релігійної самобутності кримських татар та надає їм статус корінних народів. Це гарантує захист та здійснення невід'ємного права на самовизначення татарського народу в суверенній та незалежній державі Україна. Крім того, визнає Меджліс кримських татар і Курултай найвищим представницьким органом кримських татар, як суб'єкта державної етнополітики в Україні.

\section{Список використаних джерел:}

1. Державний комітет статистики України. Про кількість та склад населення України за підсумками Всеукраїнського перепису населення 2001 року [Електронний ресурс] / Державний комітет статистики України. - 2001. - Peжим доступу до ресурсу: http://2001.ukrcensus.gov.ua/results/general/nationality/.

2. Конституція Автономної Республіки Крим [Електронний ресурс]. 1998. - Режим доступу до ресурсу: https://zakon.rada.gov.ua/laws/show/350-14\#Text.

3. Конституція України від 28 червня 1996 р. //Відомості Верховної Ради України.-1996. - №30. - с. 141

4. Курултай крымскотатарского народа [Електронний ресурс]. - 2020. Режим доступу до ресурсу: http://qtmm.org/курултай.

5. Меджлис крымскотатарского народа [Електронний ресурс]. - 2020. Режим доступу до ресурсу: http://qtmm.org/ua.

6. О внесении изменений в некоторые законы Республики Крым в сфере социальной защиты населения Республики Крым [Електронний ресурс]. 2018. - Режим доступу: http://docs.cntd.ru/document/570747922.Parulski, K. (2017).

7. Обнародование результатов общекрымского референдума, состоявшегося в Автономной Республике Крым 16 марта 2014 года [Електронний ресурс] // Комиссия Автономной Республики Крым по проведению общекрымского референдума. - 2014. - $\quad$ Режим доступу до ресурсу: https://www.rada.crimea.ua/referendum/resultaty.

8. Про визнання геноциду кримськотатарського народу [Електронний ресурс] // Відомості Верховної Ради (ВВР). - 2015. - Режим доступу до ресурсу: https://zakon.rada.gov.ua/laws/show/792-19\#Text.

9. Про національні меншини в Україні [Електронний ресурс] // Відомості Верховної Ради України (ВВР). - 1992. - Режим доступу до ресурсу: https://zakon.rada.gov.ua/laws/show/2494-12\#Text. 
10. Про Заяву Верховної Ради України щодо гарантії прав кримськотатарського народу у складі Української Держави [Електронний ресурс] // Відомості Верховної Ради (ВВР). - 2014. - Режим доступу до ресурсу: https://zakon.rada.gov.ua/laws/show/1140-18\#Text.

11. Izsák-Ndiaye R. Report of the Special Rapporteur on Minority Issues [Електронний pecypc] / Rita Izsák-Ndiaye // UN. - 2015. - Режим доступу до pecypcy: https://digitallibrary.un.org/record/797194.

12. Olszański T. A. Tatarzy Krymscy po aneksji półwyspu przez Rosję [Електронний ресурc] / Olszański // Komentarze OSW. - 2014. - Режим доступу до реcypcy: https://www.osw.waw.pl/sites/default/fi les/komentarze_141. Pdf.

13. Prawo okupacji na Półwyspie Krymskim [Електронний ресурс] // Międzynarodowe Prawo Humanitarne. - 2017. - Режим доступу до ресурсу: https://www.amw.gdynia.pl/images/AMW/Menuzakladki/Nauka/Mi\%C4\%99dzynar odowe_Prawo_Humanitarne/Publikacje/MPH\%20VIII\%20gotowe.pdf.

14. Uehling G. Livelihoods of Former Deportees in Ukraine [Електронний pecypc] / Uehling. - 2004. - Режим доступу до ресурсу: https://www. fmreview.org/sustainable-livelihoods/uehling.

15. UNHCR. Chronology for Crimean Tatars in Ukraine [Електронний реcypc] / UNHCR // Minorities at Risk Project. - 2004. - Режим доступу до ресурсу: https://www.refworld.org/docid/469f38ec14.html.

16. Voytyuk O. Deportacja Tatarów Krymskich w 1944 roku oraz jej skutki / Oksana Voytyuk. - Białystok, 2016. - 19 c. - (Białostockie Teki Historyczne).

17. Zaloznaya M. Migration as Social Movement: Voluntary Group Migration and the Crimean Tatar Repatriation / M. Zaloznaya, G. Theodore P.., 2012. - 512 c. - (Population and Development Review). - (38; 2).

\section{References:}

1. Derzhavnyi komitet statystyky Ukrainy. Pro kilkist ta sklad naselennia Ukrainy za pidsumkamy Vseukrainskoho perepysu naselennia 2001 roku [Elektronnyi resurs] / Derzhavnyi komitet statystyky Ukrainy [State Statistics Committee of Ukraine. On the number and composition of the population of Ukraine according to the results of the All-Ukrainian census of 2001]. - 2001. - URL: http://2001.ukrcensus.gov.ua/results/general/nationality/.

2. Konstytutsiia Avtonomnoi Respubliky Krym [Constitution of the Autonomous Republic of Crimea] [Elektronnyi resurs]. - 1998. - URL: https://zakon.rada.gov.ua/laws/show/350-14\#Text.

3. Konstytutsiia Ukrainy vid 28 chervnia $1996 \mathrm{r}$. [Constitution of Ukraine of June 28, 1996 // Bulletin of the Verkhovna Rada of Ukraine] //Vidomosti Verkhovnoi Rady Ukrainy. - 1996. - №30. - p. 141

4. Kurultai krymskotatarskoho naroda [Kurultai of the Crimean Tatar people]. - 2020. - URL: http://qtmm.org/kurultai.

5. Medzhlys krymskotatarskoho naroda [Mejlis of the Crimean Tatar people]. - 2020. - URL: http://qtmm.org/ua.

6. O vnesenyy yzmenenyi $\mathrm{v}$ nekotorye zakony Respublyky Krym $\mathrm{v}$ sfere sotsyalnoi zashchyty naselenyia Respublyky Krym [About modification of some 
laws of the Republic of Crimea in the field of social protection of the population of the Republic of Crimea]. - 2018. - URL: http://docs.cntd.ru/document/570747922

7. Obnarodovanye rezultatov obshchekrymskoho referenduma, sostoiavshehosia v Avtonomnoi Respublyke Krym 16 marta 2014 hoda [Announcement of the results of the all-Crimean referendum held in the Autonomous Republic of Crimea on March 16, 2014] // Commission of the Autonomous Republic of Crimea on holding the all-Crimean referendum] // Komyssyia Avtonomnoi Respublyky Krym po provedenyiu obshchekrymskoho referenduma. - 2014. - URL: https://www.rada.crimea.ua/referendum/resultaty.

8. Pro vyznannia henotsydu krymskotatarskoho narodu [On the recognition of the genocide of the Crimean Tatar people] // Bulletin of the Verkhovna Rada // Vidomosti Verkhovnoi Rady (VVR). - 2015. - URL: https://zakon.rada.gov.ua/laws/show/792-19\#Text.

9. Pro natsionalni menshyny v Ukraini [On national minorities in Ukraine // Bulletin of the Verkhovna Rada of Ukraine] // Vidomosti Verkhovnoi Rady Ukrainy (VVR). - 1992. - URL: https://zakon.rada.gov.ua/laws/show/2494-12\#Text.

10. Pro Zaiavu Verkhovnoi Rady Ukrainy shchodo harantii prav krymskotatarskoho narodu u skladi Ukrainskoi Derzhavy [On the Statement of the Verkhovna Rada of Ukraine on Guaranteeing the Rights of the Crimean Tatar People as a Part of the Ukrainian State] // Vidomosti Verkhovnoi Rady (VVR). - 2014. URL: https://zakon.rada.gov.ua/laws/show/1140-18\#Text.

11. Izsák-Ndiaye R. Report of the Special Rapporteur on Minority Issues Izsák-Ndiaye R. Report of the Special Rapporteur on Minority Issues / Rita IzsákNdiaye // UN]/ Rita Izsák-Ndiaye // UN. - 2015. - URL: https://digitallibrary.un.org/record/797194.

12. Olszański T. A. Tatarzy Krymscy po aneksji półwyspu przez Rosję [Crimean Tatars on the annexation of the peninsula through Russia] / Olszański // Komentarze OSW. - 2014. - URL: https://www.osw.waw.pl/sites/default/fi les/komentarze_141.Pdf.

13. Prawo okupacji na Półwyspie Krymskim [The right to occupy the Crimean Peninsula] // Międzynarodowe Prawo Humanitarne. - 2017. - URL: https://www.amw.gdynia.pl/images/AMW/Menuzakladki/Nauka/Mi\%C4\%99dzynar odowe_Prawo_Humanitarne/Publikacje/MPH\%20VIII\%20gotowe.pdf.

14. Uehling G. Livelihoods of Former Deportees in Ukraine / Uehling. - 2004. - URL: https://www. fmreview.org/sustainable-livelihoods/uehling.

15. UNHCR. Chronology for Crimean Tatars in Ukraine / UNHCR // Minorities at Risk Project. - $2004 . \quad-\quad$ URL: https://www.refworld.org/docid/469f38ec14.html.

16. Voytyuk O. Deportacja Tatarów Krymskich w 1944 roku oraz jej skutki [The deportation of the Crimean Tatars in 1944 was also a scourge] / Oksana Voytyuk. - Białystok, 2016. - 19 p. - (Białostockie Teki Historyczne).

17. Zaloznaya M. Migration as Social Movement: Voluntary Group Migration and the Crimean Tatar Repatriation / M. Zaloznaya, G. Theodore P., 2012. - 512 p. (Population and Development Review). 